\title{
Bilingual Classrooms in Malta: Teaching Mathematics Content and Language
}

\section{Marie Thérèse Farrugia}

\section{(2) OpenEdition \\ 12 Journals}

Electronic version

URL: http://journals.openedition.org/esp/1114

DOI: 10.4000/esp.1114

ISSN: 2532-0319

Publisher

Centre d'Information sur l'Éducation Bilingue et Plurilingue

\section{Printed version}

Date of publication: 1 June 2017

Number of pages: $61-72$

ISSN: 1127-266X

\section{Electronic reference}




\section{BILINGUAL CLASSROOMS IN MALTA: TEACHING MATHEMATICS GONTENT AND LANGUAGE}

\section{Marie Thérèse FARRUgia}

A Malta l'aula scolastica è un esempio interessante del modo in cui due lingue ufficiali si possano fondere in un contesto educativo. L'intrecciarsi delle lingue fa si che sia difficile collocare la pratica in uno dei modelli ben noti di educazione bilingue come l'immersione e CLIL (in francese EMILE, Enseignement d'une Matière par l'Intégration d'une Langue Étrangère o DNL, Disciplines Non-Linguistiques). Il contesto maltese è invece un'occasione preziosa per esplorare il processo di "translanguaging" e quest'articolo è incentrato sull'uso del maltese e dell'inglese nell'insegnamento e nell'apprendimento della matematica. Fra l'altro adottare il punto di vista secondo il quale l'apprendimento della matematica implica l'apprendimento del discorso della disciplina permette di mostrare come le pratiche pedagogiche in classe possano aver come obiettivo più esplicitamente il linguaggio matematico. La mia idea è che, così facendo, si possa puntare allo stesso tempo alla forma ed al contenuto.

Parole chiave: educazione bilingue, maltese, inglese, translanguaging, educazione matematica, contenuto e lingua

A Malte, la salle de classe est un exemple intéressant de la manière dont deux langues officielles se fondent dans un contexte éducatif. L'entrelacement des langues fait qu'il est difficile de caser la pratique dans un des modèles bien connus d'éducation bilingue tels que l'immersion et CLIL (en français EMILE, Enseignement d'une Matière par l'Intégration d'une Langue Étrangère ou DNL, Disciplines NonLinguistiques). Par contre, le contexte maltais est une précieuse occasion d'explorer le processus de "translanguaging" et cet article est centré sur l'usage du maltais et de l'anglais dans l'enseignement et l'apprentissage des mathématiques. Par ailleurs, adopter le point de vue que l'apprentissage des mathématiques implique l'apprentissage du discours de la discipline, permet de montrer comment les pratiques dans la classe peuvent viser plus explicitement le langage mathématique. Mon idée est que, ce faisant, on peut cibler tout à la fois le contenu et la langue.

Mots-clés: éducation bilingue, maltais, anglais, translanguaging, éducation mathématique, contenu et langue 


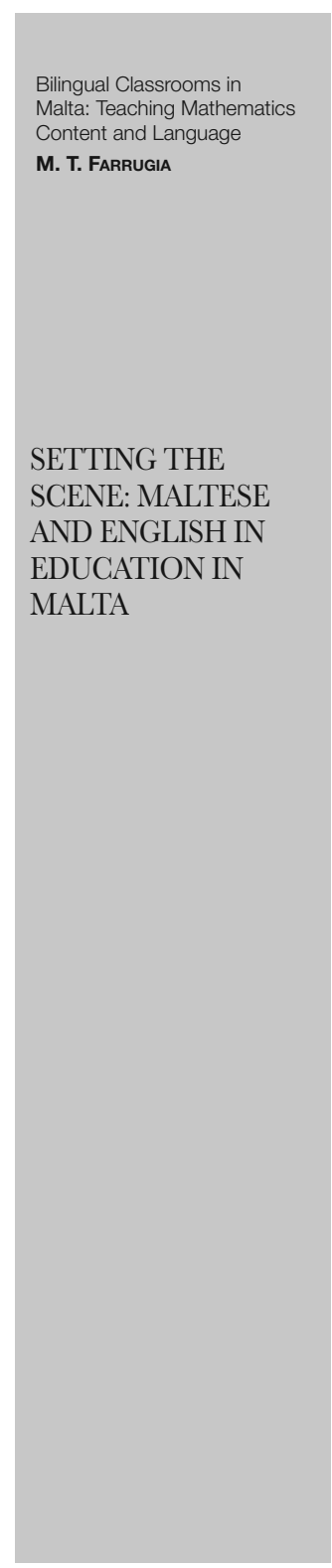

cult to fit the practice into any well-known model of bilingual education such as immersion and Content Language Integrated Learning (CLIL). Rather, the Maltese context offers a wealth of possibilities to explore the process of translanguaging and in this article, I focus on the use of Maltese and English in the teaching and learning of mathematics. Furthermore, by assuming the perspective that learning mathematics implies learning the discourse of the discipline, I show how local classroom practices may be adapted to target mathematical language more explicitly. I argue that by doing this, one can target both content and language simultaneously.

Malta has two official languages. The first is the national language, Maltese, a language with Semitic roots and a history of over 1000 years and which is spoken by more than $90 \%$ of the population (Brincat 2006). The other official language is English, which is the language of Malta's last colonisers: Malta was a British colony from 1800 until independence in 1964 . English is recognized as an important global language and is crucial for the local tourism industry. The two languages are often used - either separately or together - for the same purpose, for example within the civil administration, the media, church services and education (Camilleri Grima 2013). This results in frequent code-switching.

Maltese and English are taught as school subjects from the first year of compulsory schooling (age 5) on. While during these lessons the languages are expected to be used separately, during other lessons, it is common for both the languages to be used. Camilleri (1995) notes that the degree to which a teacher uses either language depends on their own school experiences, family background, teacher training, their students' needs and even on the School Head's preference. However, a certain similarity can be traced across classrooms. For example, from her observations in various classrooms, Camilleri (1995) noted that teachers would repeat an English explanation in Maltese to ensure students' comprehension; Maltese was also used to render the interaction more 'personal'; English on the other hand was used for subject specific terminology and also helped to bridge the spoken medium and written texts in English. Certainly, in the case of mathematics, one of the main reasons why English is used is that the textbooks are UK publications. Indeed, all written work is done in English, which is assumed to be the 'academic' language of the subject. To date, there is no standardised 


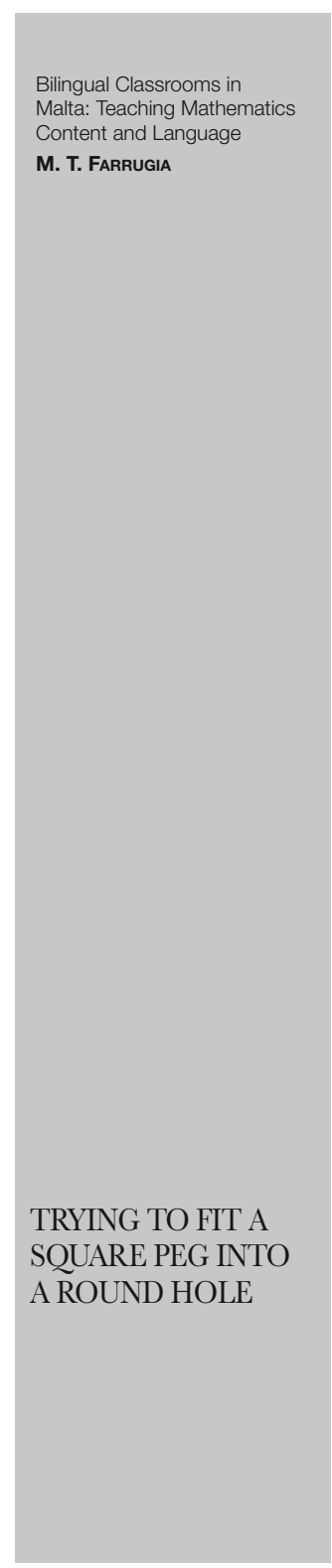

Maltese academic language for school mathematics, even though Maltese is an official EU language, and in a variety of areas, papers are published by the EU Commission in technical Maltese.

The necessity of using English in classrooms - in general and for mathematics - is increasing over time as more and more non-Maltese students receive their education in Malta. These children may be more likely to know - or be supported by their families to learn - English rather than Maltese, and hence, their teachers may be prompted to use more English, at least until these new-comers become familiar with the Maltese language. The increase in the number of such students is partly due to the movement of families within Europe (Malta joined the European Union in 2004), and to the relative safety offered to people escaping difficult political situations in their own home country. The official statistics for 2014 give $6 \%$ as the proportion of students in the state school system having at least one non-Maltese parent (Ministry for Education and Employment 2014).

As noted by García and Kleyn (2016), codeswitching is commonly practised in post-colonial education contexts, where the medium of instruction is often different from the language spoken by the students, and the students' language is used to aid comprehension. García and Kleyn consider the practice of switching as 'translanguaging' by which they mean the "deployment of a speaker's full linguistic repertoire" (2016: 14). García and Kleyn reject what they consider to be socially and politically defined boundaries of named languages (e.g. English / Maltese). In this article, I use the term 'translanguaging', but my stance is what García and Kleyn call a 'weak version' of translanguaging, i.e. supporting named language boundaries but calling for a softening of these boundaries.

Given the type of interaction common in Maltese mathematics classrooms, it is not possible to label the approach under wellknown bilingual systems such as immersion, transitional, dual or Content Language Integrated Learning programmes (Camilleri Grima, personal communication). (For detailed explanations of various types of bilingual education, the reader is referred to Baker 2011). One key aspect that hinders labelling is that, unlike internationally known approaches, local schools generally lack an official, structured programme. The Maltese National Curriculum Framework (2011: 51) gives only the general guide- 


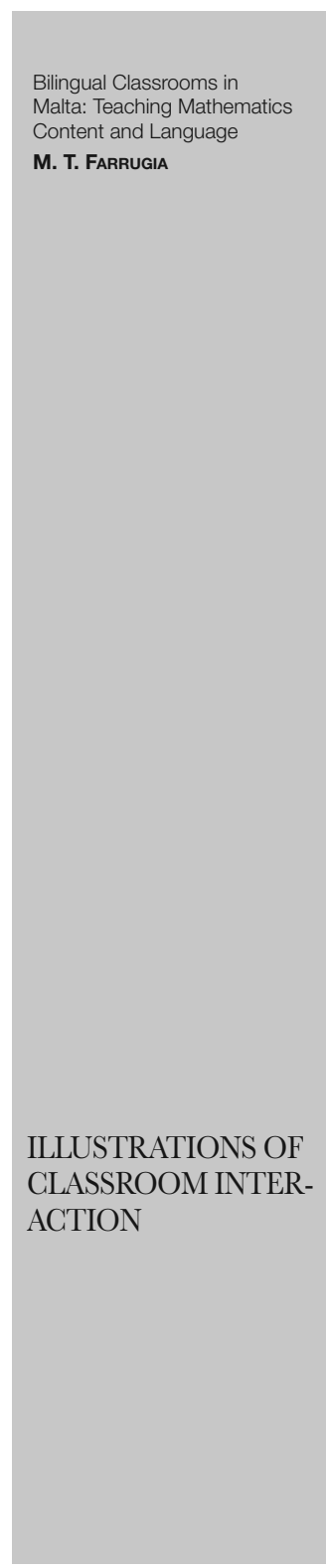

line that "mathematics concepts and language are [to be] inculcated through systematic teaching and learning activities". Hence language use remains quite 'fluid'. For example, in a particular school, there might be an 'English only' day held once a week, which may or may not be strictly adhered to; a Head of school might encourage staff to teach mathematics in English, yet it is likely that the teachers would be free to use their discretion; in some schools the presence of non-Maltese students might prompt the use of more English than in another school. In classrooms where a good amount of English is used, the approach used might be likened to immersion. In this approach, students are expected to acquire the second language by means of learning the subject through it. Language learning aims are implicit rather than explicit and in Farrugia (2009), I discuss issues that may arise in Maltese classrooms when this approach is used. However, considering the characteristics of immersion programmes given by Baker (2011), the use of English in Maltese classrooms does not fit the description. For example, our students may have potentially differing levels of English proficiency so one cannot say that they enter with similar (limited or non-existent) levels; neither is the immersion language largely confined to the classroom. If I consider instead the Content and Language Integrated Learning approach (CLIL), then again, there are differences between the local use of language and key features of CLIL. To mention two features, the target language is not a foreign language, as is usually the case in CLIL, and intercultural appreciation is not an objective. Ultimately, trying to label local use of English in teaching mathematics under internationally recognised programmes is like trying to 'fit a square peg into a round hole.'

As an illustration, I now give brief excerpts taken from two different primary classrooms that I observed in my role as researcher. In the transcripts, $\mathrm{T}$ refers to the teacher, $\mathrm{S}$ to students; English speech is shown in italics. 


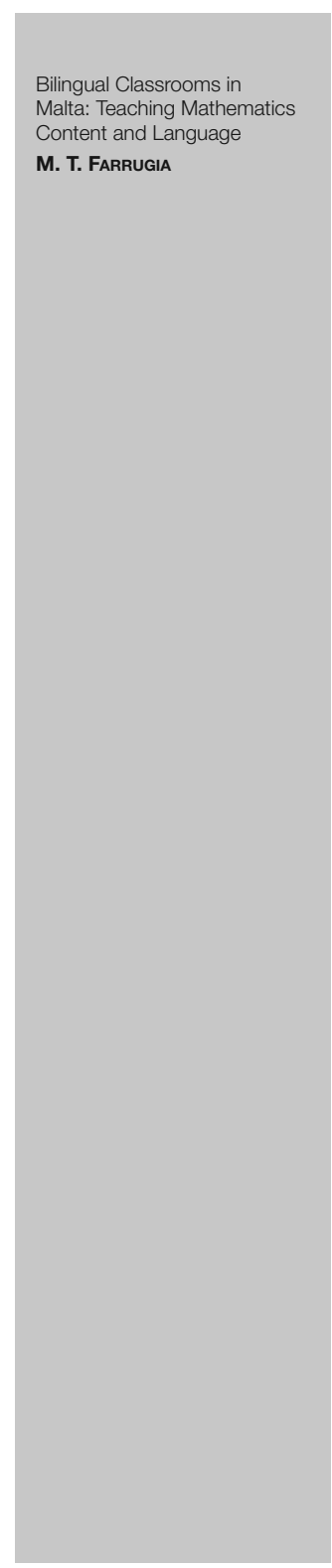

\section{EXAMPLE 1. YEAR 4 (8-9 YEAR OLDS); TOPIC 'GREATER / LESS THAN' AND ASSOCIATED SYMBOLS > AND < ORIGINAL TRANSLATION}

\begin{tabular}{|c|c|c|}
\hline $\begin{array}{l}\text { T1 } \\
:\end{array}$ & $\begin{array}{l}\text { Hawnhekk ghandkom } \\
\text { explanation qasira ta' dak li } \\
\text { ghadni kemm ghamilna. Xi } \\
\text { jfissru s-signs u kif } \\
\text { nużawhom. Qegћdin } \\
\text { tarawhom pereżempju dawn } \\
\text { in-numri? (Touches two } \\
\text { numbers shown on the } \\
\text { whiteboard). Three hundred } \\
\text { eighty five and four hundred } \\
\text { fifty eight. Issa, Karl, minn } \\
\text { dawk iż-żewg numri, liem hu } \\
\text { l-kbir? }\end{array}$ & $\begin{array}{l}\text { Here we've got a short } \\
\text { explanation about what we've } \\
\text { just done. What the signs mean } \\
\text { and how to use them. Can you } \\
\text { see these numbers, for } \\
\text { example? (Touches two } \\
\text { numbers shown on the } \\
\text { whiteboard). Three hundred } \\
\text { eighty five and four hundred } \\
\text { fifty eight. Now Karl, which of } \\
\text { these two numbers is the } \\
\text { bigger? }\end{array}$ \\
\hline S: & Four five eight. & Four five eight. \\
\hline $\mathrm{T} 1$ & $\begin{array}{l}\text { U qieghed fuq in-naha tal-left } \\
\text { jew tar-right? }\end{array}$ & $\begin{array}{l}\text { And is it on the left or on the } \\
\text { right? }\end{array}$ \\
\hline S: & Right. & Right. \\
\hline $\begin{array}{l}\text { T1 } \\
:\end{array}$ & 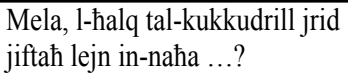 & $\begin{array}{l}\text { So, the crocodile's mouth is } \\
\text { going to open toward the ...? }\end{array}$ \\
\hline S: & Tar-right. & The right. \\
\hline
\end{tabular}

In this classroom, the teacher tended to use Maltese as the main language of communication. However, words that were topicspecific such as sign, left/right and the numbers were spoken in English. Of course, in everyday life the words for left and right in Maltese (ix-xellug/il-lemin) are commonly known. However, in the classroom, they were uttered in English because they formed part of the 'academic' language that was key to the topic at hand. 


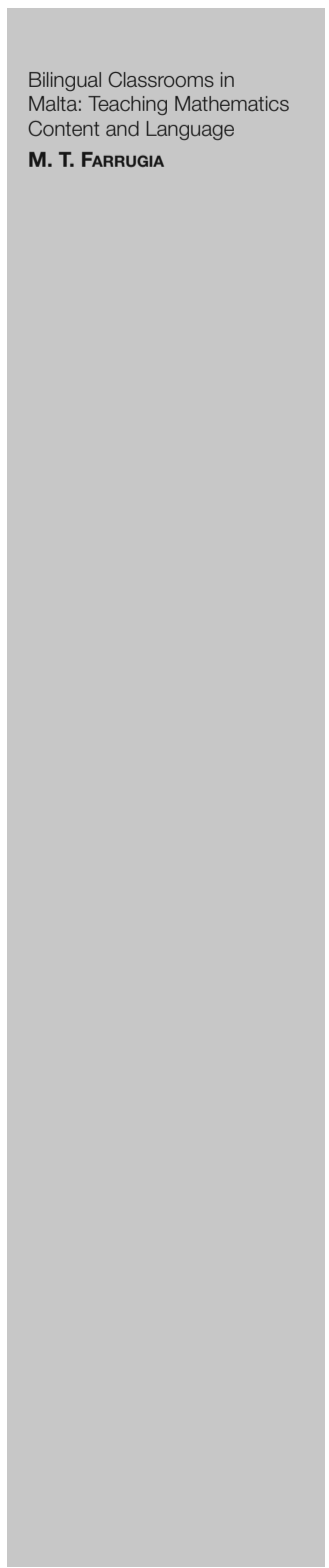

EXAMPLE 2. YEAR 3 ( 7 - 8 YEAR OLDS);

TOPIC 'MONEY'.

\section{ORIGINAL}

\begin{tabular}{|l|l|l|l|}
\hline T2 & Which coin has the smallest & Which coin has the smallest
\end{tabular}

value? (Writes this on the value? (Writes this on the

whiteboard). What am I

asking? X'qed nistaqsi

hawn? Which coin has the smallest value?

\begin{tabular}{|c|c|c|}
\hline S1: & L-iżghar. & The smallest. \\
\hline $\mathrm{T} 2$ & Kif tidher? & As in the way it looks? \\
\hline Ss: & (In chorus). Le. & (In chorus). No. \\
\hline $\begin{array}{l}\text { T2 } \\
:\end{array}$ & $\begin{array}{l}\text { OK. Mela x'inhu? Liema hi } \\
\text { dik il-kelma li qalet Fiona, } \\
\text { the magic word? Which coin } \\
\text { has the smallest value? } \\
\text { X'qed nistaqsikom? }\end{array}$ & $\begin{array}{l}\text { OK. So what is it? What's } \\
\text { that word that Fiona } \\
\text { mentioned, the magic word? } \\
\text { Which coin has the smallest } \\
\text { value? What am I asking? }\end{array}$ \\
\hline S2: & Kemm tiswa. & What it's worth (its value). \\
\hline & $\begin{array}{l}\ldots . \text { (A short while later } \\
\text { during role play with grocery } \\
\text { items). }\end{array}$ & $\begin{array}{l}\ldots . \text { (A short while later } \\
\text { during role play with grocery } \\
\text { items). }\end{array}$ \\
\hline $\begin{array}{l}\mathrm{T} 2 \\
:\end{array}$ & $\begin{array}{l}\text { Kemm jiswa ić- Chicken } \\
\text { Soup? }\end{array}$ & $\begin{array}{l}\text { How much does the Chicken } \\
\text { Soup cost?] }\end{array}$ \\
\hline Ss: & Forty. & Forty. \\
\hline $\begin{array}{l}\mathrm{T} 2 \\
:\end{array}$ & $\begin{array}{l}\text { Forty cents. How much does } \\
\text { it COST? }\end{array}$ & $\begin{array}{l}\text { Forty cents. How much does } \\
\text { it COST? }\end{array}$ \\
\hline S1: & Forty cents. & Forty cents. \\
\hline $\mathrm{T} 2$ & (Nods). Forty cents. & (Nods). Forty cents. \\
\hline
\end{tabular}

Teacher 2 used more English than Teacher 1. This teacher's general strategy was to discuss a point in Maltese, then 'repeat' the discussion in English. For example, both the former and the latter part of the excerpt cited above followed similar conversations carried out in Maltese that focused on the same mathemat- 


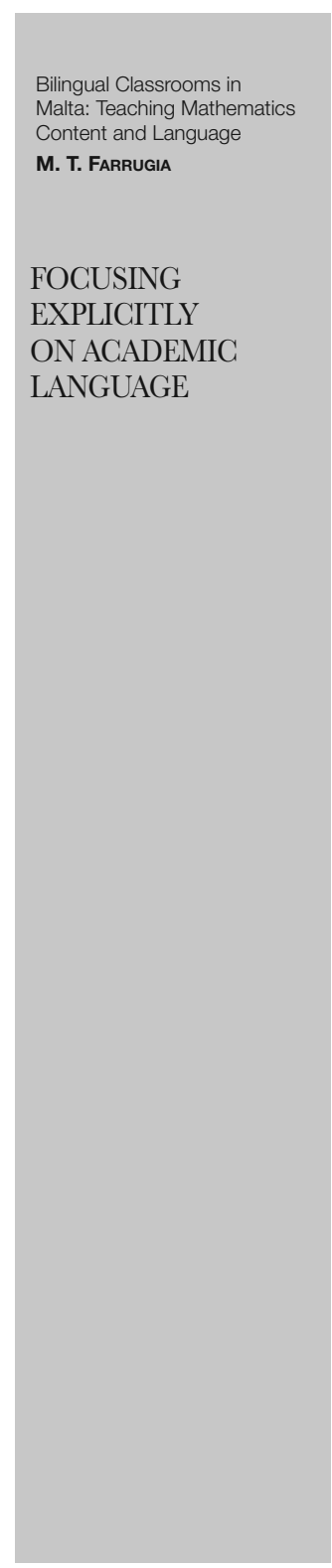

ical point and included the Maltese words for coin, value and change. This was possible due to the 'every day' nature of the topic at hand; such a translation may not be possible for topics in which Maltese equivalents are not commonly used or do not exist as standard expressions, such as in the case of polygons, square root, product and function.

As a mathematics educator, it is not so important for me to label the approach to using English under any specific type of programme; rather, it is more useful to consider the relationship between mathematics and language in terms of the development and use of academic language. Indeed, Dalton-Puffer (2011) notes that attention to academic language is a more recent development within the CLIL perspective which goes beyond a focus on vocabulary, phonology and sentence grammar more commonly associated with early foci in CLIL. For example, Morton (2010) notes how the focusing on classroom genres promoted oral and written literacy in CLIL learners in Spanish social science lessons at secondary level. Similarly, Mohan and Slater (2005) describe science lessons conducted with ESL 6-to-7 year olds in Canada, during which their teacher took great care to help the students build up targeted taxonomies and causeeffect relations. It is worth noting that scholarly works on CLIL applied to mathematics are limited. For example, in a book on teaching other subjects through English by Deller and Price (2007), only 4 out of the 67 sample lessons deal specifically with mathematics. Notable exceptions are research articles by Jäppinen (2005) and Ouazizi (2016) who report on quantitative research linking language and mathematics. On the other hand, a number of mathematics education researchers stress the need to focus on language explicitly, with both first and second language learners, giving practical suggestions on how this might be done (see, for example, Bresser, Melanese and Sphar 2009).

Both Morton (2010) and Mohan and Slater (2005) cited above use a functional view of language in their research. This view foregrounds the function that language serves in a particular context, in contrast to a view of language that is concerned with form. A key exponent of this view is Halliday (see, for example, 1978 and later works). Halliday refers to a set of meanings, together with the words and structures which express these meanings, as a 'register'. So, for example, the spoken discourse of a mathematics classroom constitutes a mathematics register. Mohan and Slater (2005) state that a functional view of lan- 


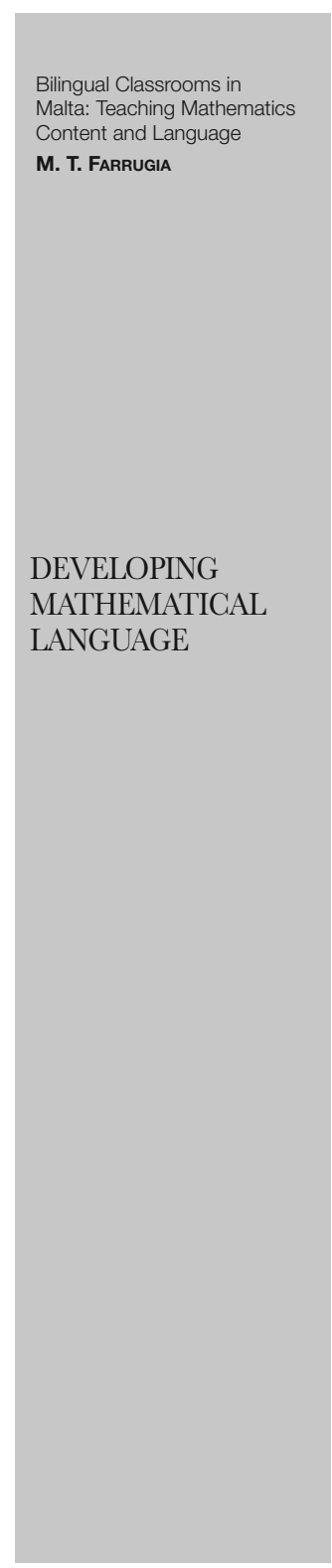

guage offers a way to characterize content and language; they explain that broadly speaking, 'content' is the meaning of a discourse, while 'language' is the wording of a discourse. Indeed, writing about CLIL research, Nikula, Dalton-Puffer and Llinares (2013) state that a functional approach allows for an integrated analysis. Taking this view allows us to do away with the separation of content/language implied in the acronym 'CLIL'. I follow Barwell (2005) in noting that such a separation is problematic for mathematics educators who view the learning of mathematics as the appropriation of a particular discourse through a social activity. Within this activity, participants (students) are supported in learning the discourse of mathematics and, as stated by Pimm (1987) in his classic book, learning to 'speak mathematically' implies learning to mean mathematically.

Writing with a focus on CLIL, Coyle, Hood and March (2010) stress that identifying the language necessary for particular subjects demands systematic analysis at the planning stage. The analysis goes beyond key words and/or grammar, but addresses progression in form and function, process and outcomes, and encourages creative use of spontaneous language by learners. This recommendation concurs with that given by Gibbons (2015), who advises that subject objectives or outcomes should be lined up with language outcomes at the planning stage. She stresses that the language would not be all the language that may occur, but that which is essential to an understanding of the concepts and/processes at hand. As an illustration of this approach, I present an overview of a series of lessons I myself delivered in a Maltese classroom as part of a wider research project. 


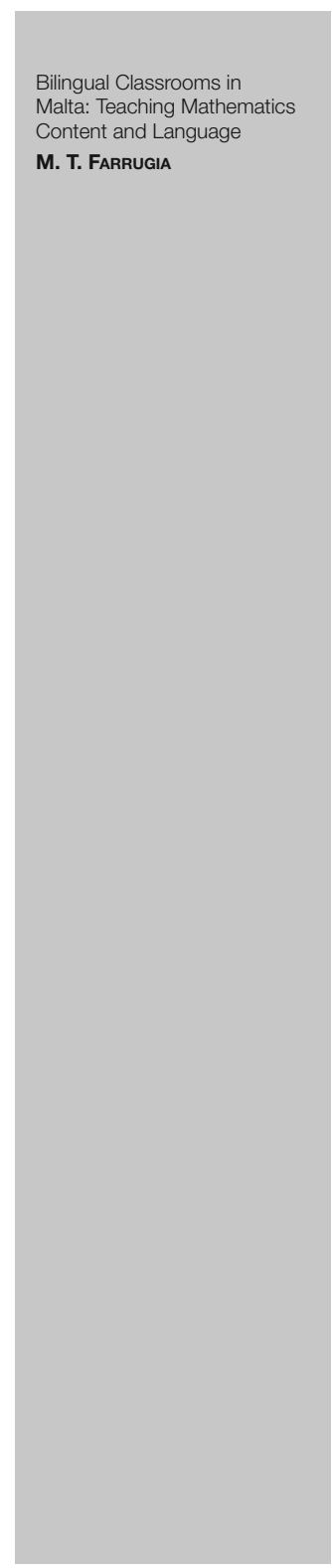

CLASS:

Grade 4, students aged 8-9 years; 16 children

STUDENTS' BACKGROUND:

All students except one had Maltese parents. One student had a Belarussian parent, but spoke Maltese fluently. English was a second language for all students.

\section{MATHEMATICAL TOPIC:}

Fractions of regions (e.g. $3 / 4$ of a circle); fractions using 'Cuisenaire' coloured rods; fractions of quantities (e.g. 1/4 of a set of 12 cards).

MEDIUM OF INSTRUCTION:

Translanguaging between Maltese and English

\begin{tabular}{|l|l|}
\hline Mathematical focus and ... & .. Related language focus \\
\hline $\begin{array}{l}\text { Area model. Fractions of regions } \\
\text { (shapes) (shading, recognising, } \\
\text { comparison, importance of equality } \\
\text { of parts) }\end{array}$ & $\begin{array}{l}\text { Equal parts / whole; The top/bottom } \\
\text { number is called the } \\
\text { numerator/denominator; the } \\
\text { numerator/denominator shows us ...; } \\
\text { the fraction is one fourth because ...; } \\
\text { two parts out of three are shaded, so } \\
\text { the fraction is ...; I think that this } \\
\text { fraction is two-thirds - am I right? }\end{array}$ \\
\hline $\begin{array}{l}\text { Length model. Fractions with } \\
\text { Cuisenaire rods }\end{array}$ & $\begin{array}{l}\text { The red rod is half the green rod; one } \\
\text { fourth of the pink rod is the white } \\
\text { rod. }\end{array}$ \\
\hline Set model. Fractions of quantities. & $\begin{array}{l}\text { One third of twelve is four } \\
\text { because... }\end{array}$ \\
\hline
\end{tabular}

While I initiated lessons using both Maltese and English, and at times explained and discussed in Maltese, there were times in the lessons when I purposely switched to using only English. The language structures listed above were modelled by myself or presented explicitly to the students in the form of 'sentence frames' which students were then expected to use in class discussion. Whole-class discussions proved to be particularly helpful segments of the lesson during which to focus on the academic language, since during paired activities, there was the tendency for the students to use both Maltese and English, and to communicate much more informally. I must state that I did not put any pressure on the students to use English. Rather, I made it clear through my teaching approach that they could use Maltese 


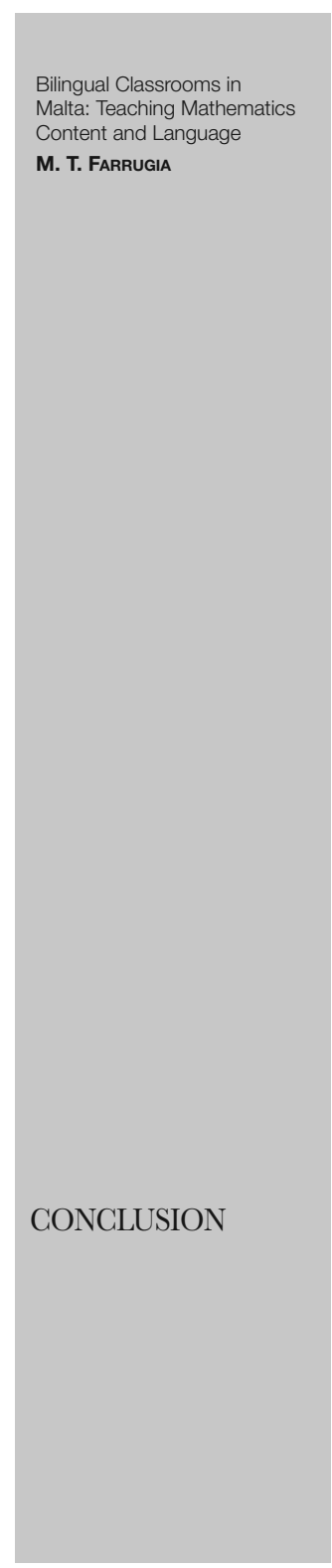

if, and when, they wished. However, they appeared to use English willingly.

Encouraging the students to use the language cited above was instrumental in increasing their verbal participation in the lessons and engaging in the discourse of mathematics. For example, the use of the structure "one fourth of sixteen is four because ..." resulted in students expressing number relationships as follows:

S1: $\quad$ Because four times four is sixteen.

S2: $\quad$ Because the ... four plus four plus four plus four is sixteen.

S3: Because sixteen divided by four equals four. When comparing my promotion of language to a CLIL approach, I note Wolff's (2011) observation that the latter is a suitable tool to boost learner autonomy. In the context under consideration here, explicit attention to language offered the students opportunities to use the academic language in ways characteristic of the discipline. For example:

DISCUSSION:

I think that this is two-thirds. Am I right?

JUSTIFICATION:

Because the pizza is divided [into] four groups, four slices.

EXPRESSION OF RELATIONSHIPS:

The yellow [rod] is half of orange [rod]

IF / THEN STATEMENTS:

If you shade them all, [then] they will become a whole.

Language structures were offered as support, but I did not overemphasise the form of language. Rather, I considered the students to be 'emerging bilinguals' (García and Kleyn 2016) and accepted idiosyncratic expressions, except when this impinged on mathematical meaning. For example, I drew a student's attention to his mistake when he stated "Two divided by six is three".

In this article I have shown that the practice of using both Maltese and English for mathematics in Malta is quite particular and that it is difficult to label the teaching method as wellknown bilingual approaches. However, by definition, the CLIL approach attempts to give equal attention to both content and language. While I questioned the separation of the two, I noted that the dual emphasis resonates with contemporary recommendations in mathematics education to focus explicitly on the subject specific register. This recommendation is relevant to educators who view learning mathematics as participating in a social 


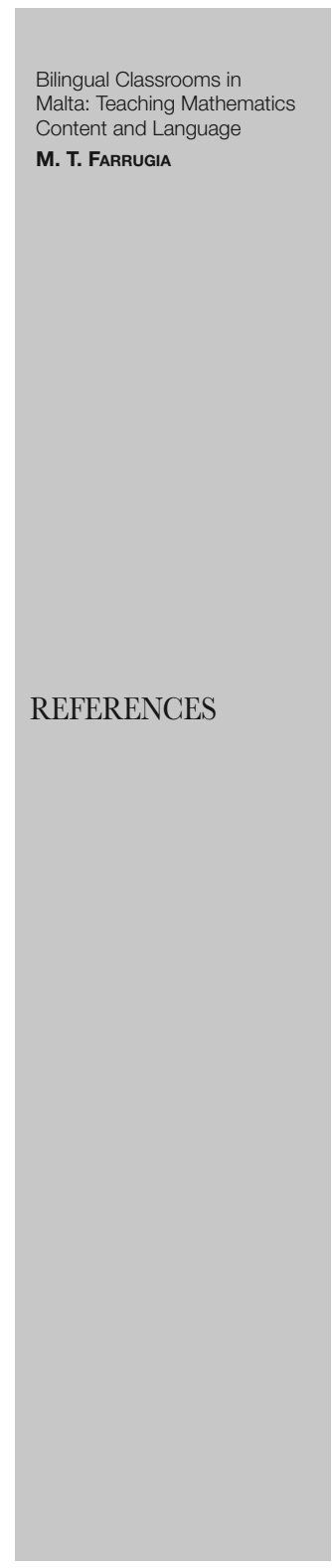

activity.

While not wishing to over-simplify the variety or complexity of classroom situations that might be found in Malta, I have offered an illustration of how a teacher might target academic language, or the discourse of mathematics, thus fulfilling both mathematical and language objectives. Using supported English for mathematics provides another, possibly new, function for the English language and may help to increase general confidence and fluency. Furthermore, planning for increased language-use by students can help to implement a pedagogy that increases students' overall participation in the classroom. In conclusion, I believe that whereas Maltese teachers should feel confident in their translanguaging practices, more work can be done during pre-service and in-service training with regard to how one might focus explicitly on English academic language. I believe that in this way, content and language may be truly targeted simultaneously in Malta.

BAKER C. 2011. Foundations of Bilingual Education and Bilingualism ( ${ }^{\text {th }}$ Edition). Bristol: Multilingual Matters.

BARWELL R. 2005. Critical issues for language and content in mainstream classrooms: Introduction. Linguistics and Education, No.16 (2): 143-150.

BRESSER R., MELANESE K., SPHAR C. 2009 Supporting English language learners in math class, grades $K-2$. Sausalito, CA: Math Solutions.

BRINCAT J.M. 2006. Languages in Malta and the Maltese language. Education et Sociétés Plurilingues n 20 (juin): 7-18.

CAMILLERI A. 1995. Bilingualism in Education: The Maltese Experience. Heidelberg: Groos.

CAMILLERI GRIMA A. 2013. Challenging code-switching in Malta. Revue Française de Linguistique Appliquée, XVIII No. 2, pp.45-61.

COYLE D., HOOD P., MARSH D. 2010. CLIL: Content and Language Integrated Learning. Cambridge: University Press.

DALTON-PUFFER C. 2011. Content and language integrated learning. From practice to principles? Annual Review of Applied Linguistics No. 31, pp.182-204. doi: 10.1017/S0267190511000092 DELLER S., PRICE C. 2007. Teaching Other Subjects Through English. Oxford: University Press. 


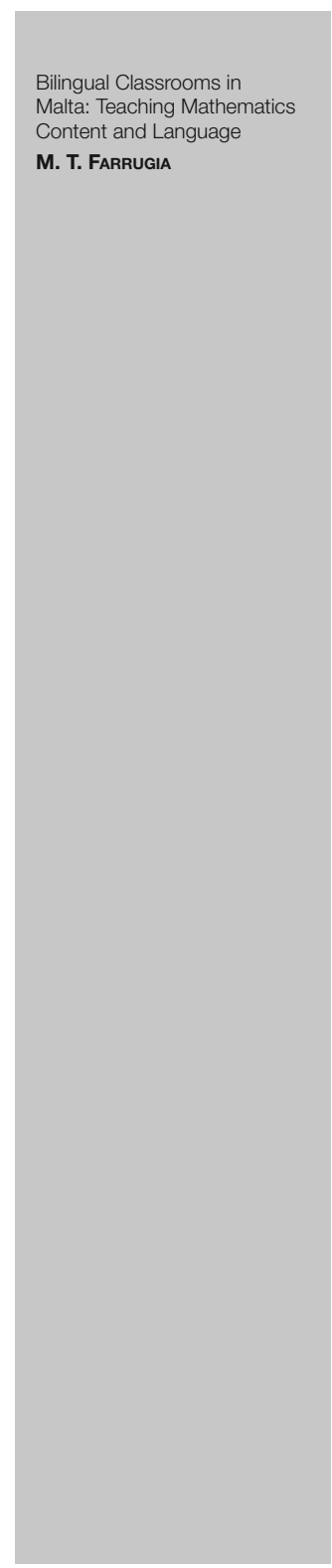

FARRUGIA M. T. 2009. Reflections on a Medium of Instruction Policy for Mathematics in Malta pp. 97-112 in BARWELL R. (ed.): Multilingualism in Mathematics Classrooms: Global Perspectives. Bristol: Multilingual Matters.

GARCÍA O., KLEYN T. 2016. Translanguaging with Multilingual Students: Learning from Classroom Moments. New York: Routledge. GIBBONS, Pauline 2015. Scaffolding language, scaffolding learning (2nd edition). Portsmouth, NH: Heinemann.

HALLIDAY M. A. K. 1978. Language as Social Semiotic. London: Edward Arnold.

JÄPPINEN A.-K. 2005. Thinking and content learning of mathematics and science as cognitional development in content and learning integrated learning (CLIL): Teaching through a foreign language in Finland. Language and Education, No. 19 (2): 147-168. doi: 10.1080/09500780508668671.

MINISTRY FOR EDUCATION AND EMPLOYMENT. 2012. A National Curriculum Framework for All. Floriana, Malta: Author.

MINISTRY FOR EDUCATION AND EMPLOYMENT 2014. Data compiled regarding student population as at 24 October 2014. Floriana, Malta: Author.

MOHAN B., SLATER T. 2005. A functional perspective on the critical 'theory/practice' relation in teaching language and science. Linguistics and Education, $\mathrm{N}^{\circ} 16$ (2): 151-172. doi:10.1016/j.linged.2006.01.008

MORTON T. 2010. Using a genre-based approach to integrating content and language in CLIL: The example of secondary history, pp. 81-104 in NIKULA T. et alii (eds.), Language use and language learning in CLIL classrooms. Amsterdam: John Benjamins. NIKULA T., DALTON-PUFFER G., LLINARES A. 2013. CLIL classroom discourse: Research from Europe, fournal of Immersion and Content-Based Language Education, $\mathrm{N}^{\circ} 1$ (1): 70-100. doi: 10.1075/jicb.1.1.04nik

OUAZIZI K. 2016. The effects of CLIL education on the subject matter (mathematics) and the target language (English), Latin American Fournal of Content and Language Integrated Learning, No. 9 (1): 110-137. doi: 10.5294/laclil.2016.9.1.5

PIMM D. 1987. Speaking Mathematically: Communication in Mathematics Classrooms. London: Routledge.

WOLFF D. 2011. CLIL and learner autonomy: relating two educational concepts, Education et Sociétés Plurilingues n 30 (juin): 69-80. 